Research Article

\title{
Assessment of Irrigation Development in the Small Dams Command Area: A Case Study of Palai Dam, District Charsadda
}

\author{
Muhammad Jamal Nasir*, Atiq Ur Rahman and Anwar Saeed Khan
}

Department of Geography, University of Peshawar, Khyber Pakhtunkhwa, Pakistan.

\begin{abstract}
The total cultivated area of Khyber Pakhtunkhwa is 1.65 million hectares out of which only 0.86 million hectares are irrigated while the remaining 0.79 million hectares have no permanent water for agriculture and mostly dependent on rainfall for irrigation. The development and management of water resources are of extreme importance for the sustainable development of agriculture specifically in rain-fed areas. Palai dam is a small irrigation dam, constructed on River Jindi, some $40 \mathrm{~km}$ north of Charsadda town. The present study is an attempt to evaluate the impact of the Palai dam on the irrigation system of selected villages of tehsil Tangi. The study is based on an analysis of revenue data acquired from revenue office Tangi, between 2008-09 to 2016-17. The geospatial analysis of collected data is done using the software ArcGIS 10.5.2. The analysis revealed a tremendous increase in canal irrigated area. Before construction of the dam in 2008-09, the canal irrigated area in Palai Nasratzai was 138 acres (5.39\% of the total cultivated area), which increased to 1348 acres (52\% of the total cultivated area) after construction of the dam in 2016-17. During the same period, the rain-fed area decreased from 1791 acres to 604 acres. A similar trend was identified in village Qilla, where before the dam construction, there was no concept of canal irrigation, but after the dam construction, $64.36 \%$ of cultivated land is now being irrigated through the Palai irrigation canal. Similarly, the tubewell irrigated area decreased from $87.29 \%$ to $30.07 \%$ of the irrigated area after the dam construction.

Received | July 15, 2019; Accepted | November 05, 2020; Published | January 22, 2021

*Correspondence | Muhammad Jamal Nasir, Department of Geography, University of Peshawar, Khyber Pakhtunkhwa, Pakistan; Email: drjamal@uop.edu.pk,drjamal.geog@gmail.com

Citation Nasir, M.J., A.U. Rahman and A.S. Khan. 2020. Assessment of irrigation development in the small Dams command area: A case study of Palai Dam, District Charsadda. Sarhad Journal of Agriculture, 37(1): 43-51.

DOI | http://dx.doi.org/10.17582/journal.sja/2021/37.1.43.51

Keywords | Palai dam, Canal irrigation, Cultivated land, Spatial analysis, Revenue record
\end{abstract}

\section{Introduction}

I rrigation, the watering of land has become an integral part of agriculture, without which crops cannot grow properly. Globally 20 percent of the total cultivated land gets irrigation water to produce 40 percent of food worldwide (FAO, 2015). In SubSaharan Africa (SSA) only 4 percent of the cultivated land is irrigated (Burney et al., 2013), in Asia this ratio is 41 percent, which tenfold as of SSA (Portmann et al., 2010). Irrigation together with improved inputs and mechanization significantly contributed to the green revolution in Asia (Hazell, 2009). However, due to rapid population growth, agricultural production needs to be intensified to ensure food security. Schultz et al. (2005) found that 90\% of the increase in production must be accomplished from already cultivated land and only 10 percent by bringing new land under plough. Sustainable intensification is necessary for irrigated and rainfed agriculture; however, irrigated agriculture has a higher potential for agricultural intensification (FAO, 1997). Irrigation has a positive impact on agricultural production and in turn the socioeconomic condition of an area. However, the existing literature on irrigation and its impact on agricultural 
production and socio-economic conditions of farmers is diverse and polarized. According to Fan et al. (2000), government expenditures on irrigation has a negligible impact on agricultural performance. Similarly, Jin et al. (2002), determined no connection between irrigation improvement and agriculture productivity. The same results have been communicated by Portmann et al. (2010). However, the positive impact of irrigation on agricultural production and in turn on livelihoods of various communities in Africa have been communicated by several researchers (Mati, 2008; Bacha et al., 2011; Hagos et al., 2012; Namara et al., 2013; Shah et al., 2013; Amede, 2015; Tolera, 2017; Ayala et al., 2018).It is possible to manipulate agricultural production and timing by a more reliable and all-year-round supply of irrigation water (Tolera et al., 2017; Lata, 2019).

In Pakistan, the total cultivated land accounts for 54.7 million acres, out of which 42.0 million acres (76.71\%) is irrigated, while 12.7 million acres (23.28\%) depends on rainfall for crop production. Out of 12.7 million acres, rain-fed irrigated land, 4.2 million acres' land has the potential for canal irrigation (Ashraf et al., 2007). The total area of Khyber Pakhtunkhwa is 14.1 million acres, out of which only $28.86 \%$ is cultivated (4.0 million acres) while remaining, 71.14 percent is uncultivated. Out of 4.0 million acres of cultivated land, only 2.1 million acres are irrigated, thus 1.9 million acres ( $47.87 \%$ of total cultivated land) have no ensured water for agriculture and mostly dependent on rainfall for irrigation (GoKP, 2016). Even in these rain-fed areas due to uncertainty of rainfall, both in time and amount, farmers use minimum inputs due to the risk of crop failure and hence cause wide food insecurity. In rain-fed areas, agricultural production can be enhanced by either raising the yield per hectare or by bringing more area under the plough. In both cases, the water appears to be the most important determining factor (Ashraf et al., 2007). The per capita water availability in Khyber Pakhtunkhwa is about $513.44 \mathrm{~m}^{3}$, far less as compared to $1200 \mathrm{~m}^{3}$ and $1000 \mathrm{~m}^{3}$ for Pakistan and at the international level respectively (GoKP, 2016) reflecting the water stress situation in Khyber Pakhtunkhwa.

Palai dam is a small dam located on the north border of District Charsadda, on River Jindai, $16 \mathrm{~km}$ north of Tangi village, and $40 \mathrm{~km}$ north of Charsadda town. Geographically, it is located on $34^{\circ}-26^{\prime}$ north latitude and $71^{\circ}-41^{\prime}$ east longitudes (Figure 1). The irrigation department approved the dam in 2006, the construction started in 2009 and completed in 2011. The dam has a drainage area of $142.45 \mathrm{sq}$. $\mathrm{km}$. The proposed command area of 4600 acres is located downstream on both sides of the river Jindai (GoKP, 1994). The main purpose of the dam is to irrigate 4600 acres of land in four villages of tehsil Tangi, District Charsadda. It was estimated that a total of $30 \mathrm{ft}^{3} / \mathrm{s}$ of irrigation water will be delivered to the feeding canal, $6.5 \mathrm{ft}^{3} / \mathrm{s}$ to $3.5 \mathrm{~km}$ long right bank canal which will irrigate 1000 acres of land, and $23.5 \mathrm{ft}^{3} / \mathrm{s}$ to the $11.7 \mathrm{~km}$ long left bank canal which is supposed to irrigate 3680 acres of land. Before the construction of the dam, only about 125 acres of land was under irrigated agriculture through lift irrigation from the river, while the rest of the area was under rain-fed cultivation. The government claimed that the cropping intensity of $130 \%$ is expected to be achieved by 2016 (GoKP, 1994). However, a very limited study of the dam has been carried out regarding its impact on the irrigation system of the command area. The present study is designed to study the impact of the Palai dam on the source of irrigation and irrigation systems of the selected villages i.e. Palai Nasratzai and Qilla Figure 1. Location of the study area.

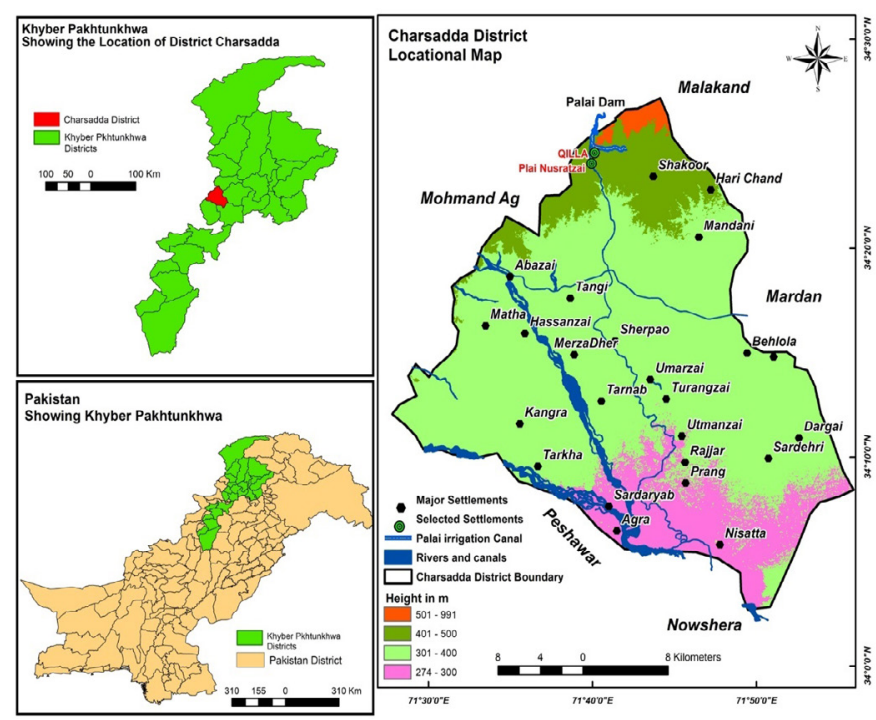

Figure 1: Location of study area.

\section{Study area}

To achieve the study objectives two villages were selected for the acquisition of revenue data. The first village was selected at the tail end of the Palai right bank canal and the second in the middle of the left bank canal. Village Qilla is located on the Palai right bank canal in Tehsil Tangi, District Charsadda. To the north of the village lies District Malakand, to the south is village Palai Nasratzai and in the east is village 
Dobandai. Geographically, it is located at $34^{\circ} 03^{\prime} 05^{\prime \prime}$ to $34^{\circ} 28^{\prime} 00^{\prime \prime} \mathrm{N}$ latitude and $71^{\circ} 20^{\prime} 00^{\prime \prime}$ to $71^{\circ} 28^{\prime} 00^{\prime \prime} \mathrm{E}$ longitude (Muhammad et al., 2017). Palai Nasratzai lies to the south of the village Qilla and irrigated through Palai left bank canal. Geographically it is located at $34^{\circ} 24^{\prime}, 20^{\prime \prime}$ to $34^{\circ} 24^{\prime} 40^{\prime \prime} \mathrm{N}$ latitude and $71^{\circ} 40^{\prime} 20^{\prime \prime}$ to $71^{\circ} 41^{\prime} 00^{\prime \prime} \mathrm{E}$ longitude. The mainstay of both the villages is agriculture, where almost every household possesses a piece of agricultural land. Figure 1. Location of study area.

\section{Material and Methods}

This study is primarily based on secondary data collected from the revenue office Tangi. The following data was collected from the revenue office:

\section{Lal kitab}

Lal Kitab (Village Notebook) prepared at the time of settlement. The kitab has information regarding crops grown and area of each parcel, soil classification, land use, means of irrigation, etc.

\section{Khasra gardawari}

Khasra Gardawari is a harvest inspection register. It is an important document in which the Patwari keep the record of the landowner. The ownership information of each individual is represented with the help of a specific number called Khasra Number. Besides it also contains the following Data:

- Khasra number (Plot number) of the parcel

- Name of Owner/Cultivator

- Area of the parcel

- Irrigation type, source of irrigation

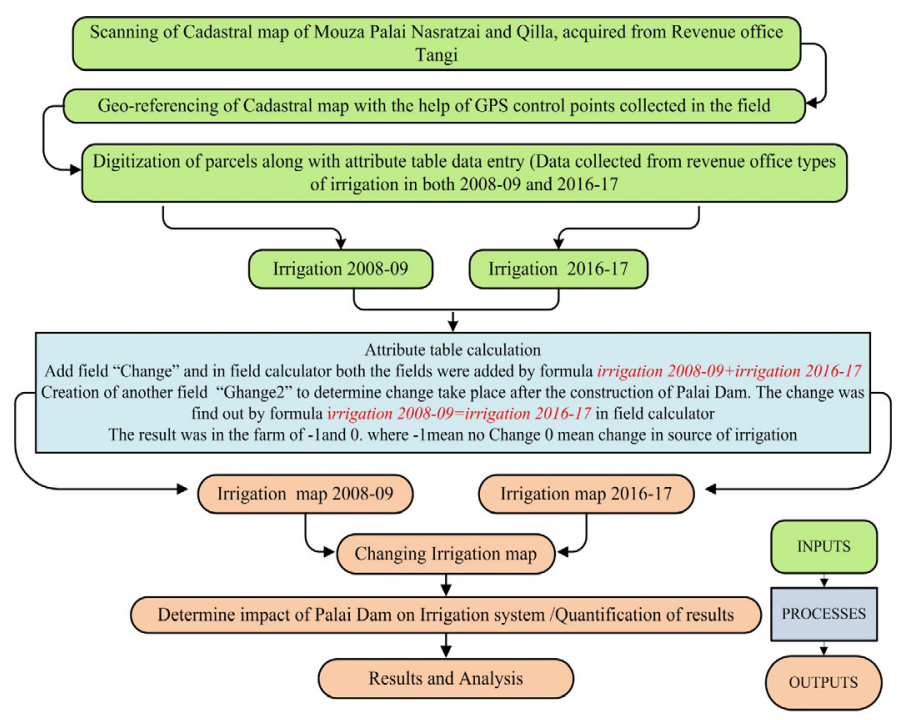

Figure 2: Methodology for analysis in Arc GIS 10.5.2.

\section{Cadastral map}

Cadastral map, Shajra or Lattha is a large scale map on which patwari shows the boundaries of the property (Parcels) along with the ownership information. Khasra number is the primary field and all other records i.e. Land use, Cropping pattern. Source of irrigation etc. are linked with Khasra number.

\section{Analysis}

Analysis of data was carried out in ArcGIS 10.5.2 environment. Figure 2 depicts the methodology adopted to achieve the study objectives.

\section{Results and Discussion}

\section{Source of irrigation in village Pali Nasrat Zai}

The Palai Dam is providing enough irrigation supplies to about 4600 acres of four villages of tehsil Tangi District Charsadda (GoKP, 1994). There is a vast stretch of agricultural land lying on both sides of the Jindi River downstream of the Palai Dam. Before Dam construction, 125 acres of land was under irrigated agriculture through lift irrigation from the river Jindi, while the rest of the area was rain-fed (Barani) cultivation. Village Palai Nasratzai is one of the four villages which get irrigation water from the Palai irrigation canal. The collected revenue record is summarized in Table 1 . The analysis of the revenue record revealed that the total area of the village is 2955 acres, out of which 2559 acres are cultivated area, irrigated by different sources. It also reveals that area net sown (the area cropped during the census year) drastically increased from 816 acres (200809) to 1915 acres with a corresponding decrease in current fallow (the area not cropped due to deficiency of water or any other input) after the construction of the dam in 2016-17. For the same period the current fallow decrease from 1743 acres to 758 acres (Muhammad et al., 2017). Similarly, 115 acres of land was Banjar qadeem (Area fit for cultivation but was not cropped for more than 5 years), which was brought under plough after the dam construction. The analysis of Table 2 and Figures 4 and 5 indicates a drastic change in the irrigation system of village Pali Nasrat Zai between 2008-09 to 2016-2017. In 2008-09, the major source of irrigation was rainfall. The rain-fed irrigated land was account for $69.98 \%$ of the total irrigated area which decreased drastically to $23.60 \%$ of the total irrigated area in 2016-2017. The decrease in rain-fed irrigation is attributed to the corresponding increase in canal irrigation. 
Table 1: Village Palai Nasrat Zai, land use 2008-09, 2016-17.

\begin{tabular}{|c|c|c|c|c|c|c|}
\hline \multirow{2}{*}{\multicolumn{3}{|c|}{ Land use categories }} & \multicolumn{2}{|c|}{ 2008-2009 } & \multicolumn{2}{|c|}{ 2016-2017 } \\
\hline & & & Area in acre & $\%$ age of total area & Area in acre & $\%$ age of total area \\
\hline \multirow{2}{*}{\multicolumn{2}{|c|}{ Cultivated }} & Net Sown Area & 816 & 27.61 & 1915 & 64.81 \\
\hline & & Current fellow & 1743 & 58.98 & 758 & 25.65 \\
\hline \multicolumn{3}{|c|}{ Total cultivated } & 2559 & 86.60 & 2673 & 90.46 \\
\hline \multirow{8}{*}{$\begin{array}{l}\text { Unculti- } \\
\text { vated }\end{array}$} & \multirow[t]{3}{*}{ Cultivable waste land } & Banjar Qadeem & 115 & 3.89 & 0 & 0.00 \\
\hline & & Natural Drainage & 39 & 1.32 & 40 & 1.36 \\
\hline & & Torrent & 19 & 0.64 & 19 & 0.64 \\
\hline & \multirow[t]{5}{*}{ Culturable waste land } & Schools & 1 & 0.03 & 1 & 0.03 \\
\hline & & Mosque & 2 & 0.07 & 2 & 0.07 \\
\hline & & Roads & 18 & 0.61 & 18 & 0.61 \\
\hline & & Path & 114 & 3.86 & 114 & 3.86 \\
\hline & & Settlement & 88 & 2.98 & 88 & 2.98 \\
\hline \multicolumn{3}{|c|}{ Total uncultivated } & 396 & 13.40 & 282 & 9.54 \\
\hline \multicolumn{3}{|c|}{ Total geographical area } & 2955 & & 2955 & \\
\hline
\end{tabular}

Source: Revenue record.

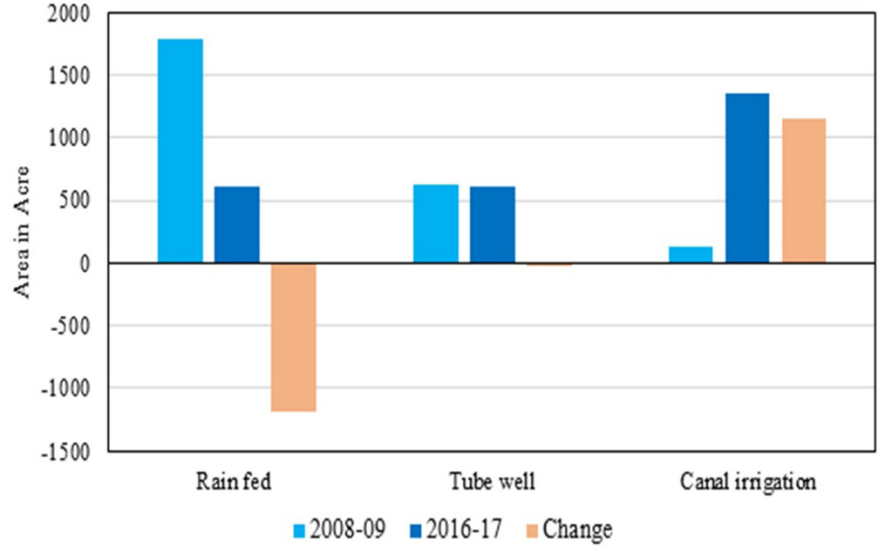

Figure 3: Village Palai Nasrat Zai, area under different irrigation source, 2008-09, 2016-17.

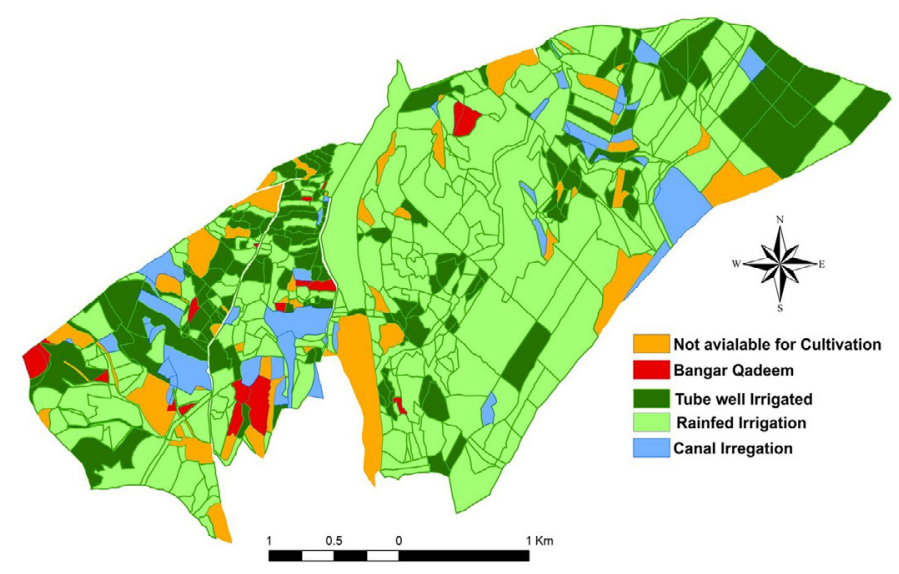

Figure 4: Source of irrigation and area under different irrigation sources of Mouza Palai Nasratzai in 2008-09.

The canal irrigated area in 2008-2009 was only 5.39\% of the total irrigated area which increased to $52.67 \%$ after the construction of the Palai Dam and Palai irrigation canal. The tubewell irrigated area showed an insignificant decrease from 630 acres (24.61\%) of the total irrigated area to 607 acres $(23.72 \%)$ in 2016-2017 Table 1. Village Palai Nasratzai, Land Use 2008-09, 2016-17 Table 2. Village Palai Nasrat Zai, area under different irrigation sources, 2008-09, 2016-17, Table 3. Village Palai Nasrat Zai Change in the source of irrigation 2008-09 to 2016-17 Figure 3. Village Palai Nasrat Zai, area under different irrigation sources, 2008-09, 2016-17 Figures 4 and 5. Source of irrigation and area under different irrigation sources of Village Palai Nasratzai in 2008-09 and 2016-17 Figure 6. Change in the source of irrigation between 2008-09 and 2016-17.

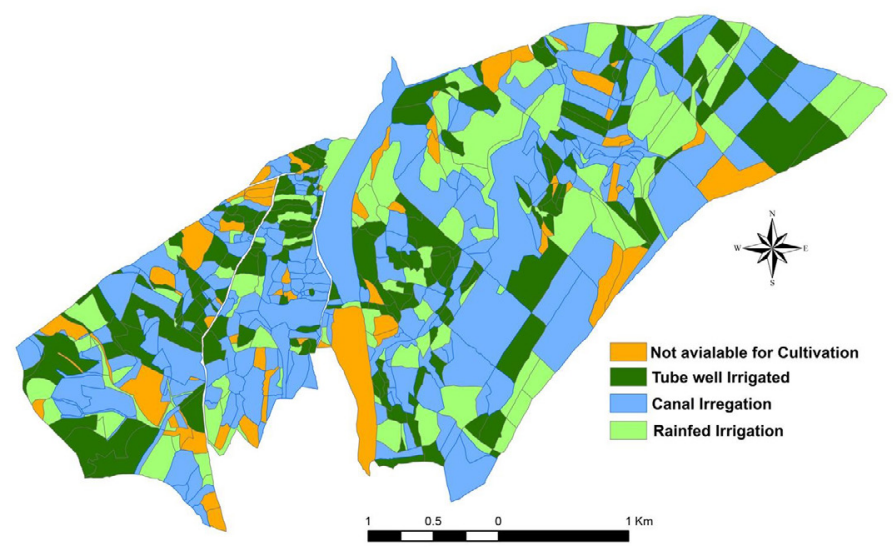

Figure 5: Source of irrigation and area under different irrigation sources of Mouza Palai Nasratzai in 2016-17.

Source of irrigation in village Qilla

The second village selected for the present study is Qilla, which is irrigated by Pali right bank canal. Qilla is a small village compared to Palai Nasrat Zai, 
Table 4: Village Qilla, land use 2008-09, 2016-17.

\begin{tabular}{|c|c|c|c|c|c|c|}
\hline \multicolumn{3}{|c|}{ Land use categories } & \multicolumn{2}{|l|}{ 2008-2009 } & \multicolumn{2}{|l|}{ 2016-2017 } \\
\hline & & & Area in acre & \%age of total area & Area in acre & \%age of total area \\
\hline \multirow{2}{*}{\multicolumn{2}{|c|}{ Cultivated }} & Net sown area & 63.37 & 11.54 & 73.75 & 13.41 \\
\hline & & Current fellow & 30.16 & 5.48 & 19.79 & 3.60 \\
\hline \multicolumn{3}{|c|}{ Total Cultivated } & 93.54 & 17.01 & 93.54 & 17.01 \\
\hline \multirow{8}{*}{$\begin{array}{l}\text { Unculti- } \\
\text { vated }\end{array}$} & Cultivable WL & Banjar Qadeem & 2.57 & 0.46 & 2.57 & 0.46 \\
\hline & \multirow{3}{*}{$\begin{array}{l}\text { N. Available for Cultiva- } \\
\text { tion }\end{array}$} & Mountain & 409.09 & 74.43 & 409.09 & 74.43 \\
\hline & & Natural drainage & 1.62 & 0.29 & 1.62 & 0.29 \\
\hline & & River Jindi & 33.34 & 6.06 & 33.04 & 6.06 \\
\hline & \multirow[t]{4}{*}{ Culturable Waste land } & Graveyard & 0.59 & 0.10 & 0.59 & 0.10 \\
\hline & & Roads & 1.54 & 0.28 & 1.54 & 0.28 \\
\hline & & Path & 0.31 & 0.05 & 0.31 & 0.05 \\
\hline & & Settlement & 7.01 & 1.27 & 7.01 & 1.27 \\
\hline \multicolumn{3}{|c|}{ Total Uncultivated } & 456.07 & 82.98 & 456.07 & 82.98 \\
\hline \multicolumn{3}{|c|}{ Total geographical area } & 549.61 & & 549.61 & \\
\hline
\end{tabular}

Source: Revenue Record.

with a total area of 549.61acres, out of which only $17.01 \%$ is cultivated while the rest $82.98 \%$ is uncultivated land. The analysis of Table 4 suggested that very little change has occurred in the land use pattern of the village Qilla after the construction of Pali Dam. However, the analysis of Tables 5 and 6 suggests that the irrigation system of the village is completely changed Table 4. Village Qilla, Land Use 2008-09, 2016-17 Table 5. Village Qilla, Area under different Irrigation sources, 2008-09 to 2016-17. Figure 7. Village Qilla, area under different Irrigation sources, 2008-09, 2016-17 Figures 8 and 9. Source of Irrigation, the irrigation system of Mouza Qilla, 2008-09 and 2016-17 respectively. Based on analysis of Revenue record acquired from revenue office Tangi District Charsadda.

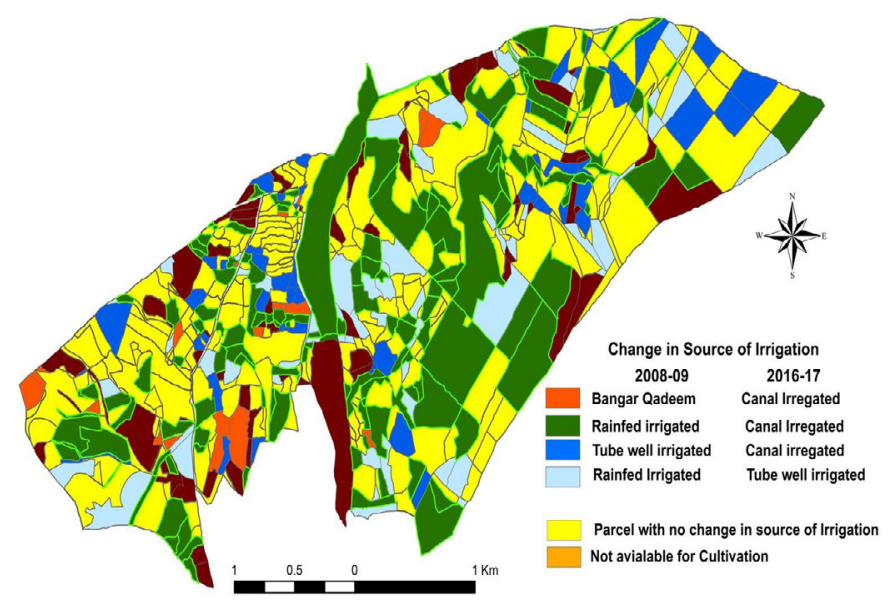

Figure 6: Change in the source of irrigation between 2008-09 and 2016-17. Source revenue record acquired from revenue office Tangi District Charsadda analyzed in Arc GIS 10.5.2.
Table 2: Village Palai Nasrat Zai, area under different irrigation sources, 2008-09, 2016-17.

\begin{tabular}{lllllll}
$\begin{array}{l}\text { Source of } \\
\text { irrigation }\end{array}$ & \multicolumn{3}{c}{$\mathbf{2 0 0 8 - 2 0 0 9}$} & \multicolumn{2}{c}{$\mathbf{2 0 1 6 - 2 0 1 7}$} & \\
& $\begin{array}{l}\text { Area in } \\
\text { acre }\end{array}$ & $\begin{array}{l}\text { Per- } \\
\text { centage }\end{array}$ & $\begin{array}{l}\text { Area in } \\
\text { acre }\end{array}$ & $\begin{array}{l}\text { Per- } \\
\text { centage }\end{array}$ & Change \\
Tube Well & 630 & 24.61 & 607 & 23.72 & -23 \\
Rain Fed & 1791 & 69.98 & 604 & 23.60 & -1187 \\
Canal Irrigation & 138 & 5.39 & 1348 & 52.67 & +1149 \\
Total & 2559 & 100.00 & 2559 & 100.00 &
\end{tabular}

Source: Revenue Record.

Table 3: Village Palai Nasrat Zai change in source of irrigation 2008-09 to 2016-17.

\begin{tabular}{|c|c|c|c|c|}
\hline \multicolumn{3}{|c|}{ Source of Irrigation } & \multirow{2}{*}{$\begin{array}{l}\text { No of } \\
\text { parcels }\end{array}$} & \multirow{2}{*}{$\begin{array}{l}\text { Area in } \\
\text { Acre }\end{array}$} \\
\hline & 2008-09 & $2016-17$ & & \\
\hline 1 & Banjar Qadeem & Canal Irrigation & 19 & 58 \\
\hline 2 & Rain fed Irrigated & Canal Irrigation & 140 & 886 \\
\hline 3 & Tube well & Canal Irrigation & 55 & 205 \\
\hline \multicolumn{3}{|c|}{ Total } & 214 & 1149 \\
\hline
\end{tabular}

Source: Revenue Record.

The analysis of Table 6, reveals that before dam construction, tubewell was a major source of irrigation which accounts for $87.29 \%$ of the total cultivated area before the construction of the Palai dam, the share of tubewells decreased drastically to $30.07 \%$ in $2016-17$. Rain-fed irrigation decreased from $12.70 \%$ (2008-09) to $5.20 \%(2016-17)$ of the total cultivated area. There was no canal irrigated land before the construction of the dam but today canal irrigation is the major source of irrigation which accounts for $64.36 \%$ of 
the total cultivated land in 2016-17 Table 6. Village Qilla, Impact of Palai Dam on Source of Irrigation 2008-09 to 2016-17 Figure 10. Change in the source of irrigation, irrigation system of Mouza Qilla, from 2008-09 to 2016-17. Based on an analysis of revenue records acquired from revenue office Tangi District Charsadda.

Table 5: Village Qilla, area under different Irrigation sources, 2008-09 to 2016-17.

\begin{tabular}{|c|c|c|c|c|c|}
\hline \multirow{2}{*}{$\begin{array}{l}\text { Source of irri- } \\
\text { gation }\end{array}$} & \multicolumn{2}{|c|}{ 2008-09 } & \multicolumn{2}{|c|}{ 2016-17 } & \multirow{2}{*}{$\begin{array}{l}\text { Change } \\
\text { in acre }\end{array}$} \\
\hline & $\begin{array}{l}\text { Area in } \\
\text { acre }\end{array}$ & $\begin{array}{l}\text { Percent- } \\
\text { age }\end{array}$ & $\begin{array}{l}\text { Area in } \\
\text { acre }\end{array}$ & $\begin{array}{l}\text { Percent- } \\
\text { age }\end{array}$ & \\
\hline Rain fed & 11.88 & 12.70 & 5.20 & 5.5 & -6.68 \\
\hline Tube well & 81.66 & 87.29 & 28.13 & 30.07 & -53.53 \\
\hline Canal irrigation & 0 & 0.0 & 60.21 & 64.36 & +60.21 \\
\hline Total & 93.54 & 100 & 93.54 & 100 & \\
\hline
\end{tabular}

Source: Revenue Record.

Table 6: Village Qilla, impact of Palai Dam on source of irrigation 2008-09 to 2016-17.

\begin{tabular}{lllll}
\multicolumn{2}{c}{ Source of Irrigation 2008-09 2016-17 } & $\begin{array}{l}\text { No of } \\
\text { parcels }\end{array}$ & $\begin{array}{l}\text { Area in } \\
\text { acre }\end{array}$ \\
\hline 1 Rain fed irrigated & Canal irrigation & 25 & 11.88 \\
2 & Tube well & Canal irrigation & 83 & 44.20 \\
Total & & 214 & 1149
\end{tabular}

Source: Revenue record.

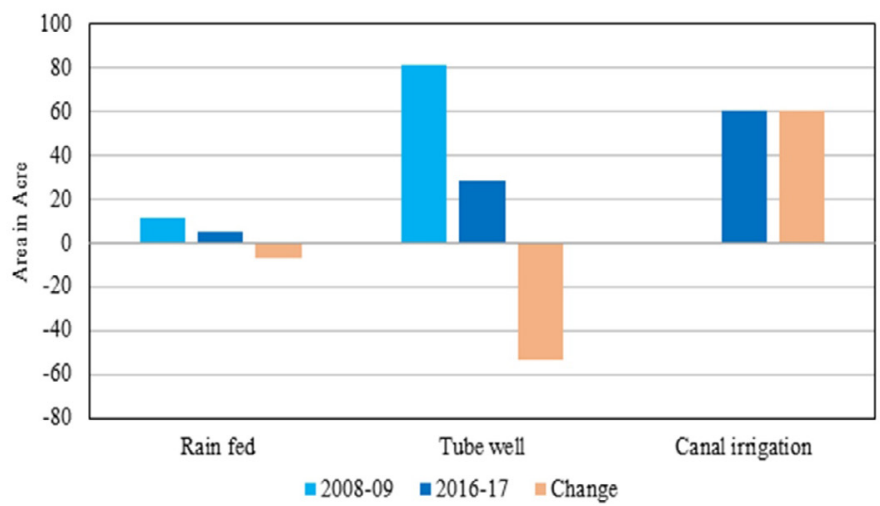

Figure 7: Village Qilla, area under different irrigation source, 2008-09, 2016-17.

Both the villages are part of the greater Peshawar valley therefore climatically suitable for year-round farming. The soil of the study area is fertile and is suitable to support a variety of crops, the only constraint is the unavailability of irrigation water, because of which most of the cultivated area was kept fallow.

\section{Irrigation system}

Communities with heavy dependence on rain- fed irrigation are more prone to water scarcity and drought which in turn significantly affect crop yield. The majority of land in both villages was rain-fed irrigated before the construction of the Palai Dam. Figure 11 reveals that rainfall is highly sporadic and variable. The rainfall in both Kharif and rabbi season is very low and is the major cause of crop failure. After the construction of the Palai dam canal irrigation has become the main source of irrigation. However, in the canal irrigation system, the availability of water is linked with the location of the village on the canal and the position of land on the watercourse. The village located close to the irrigation canal gets sufficient water compared to one located at the tail end of the canal. Similarly, land located close to the branch canal and distributaries get enough water compared to one located at minors and watercourses Figure 11. Climograph of District Charsadda.

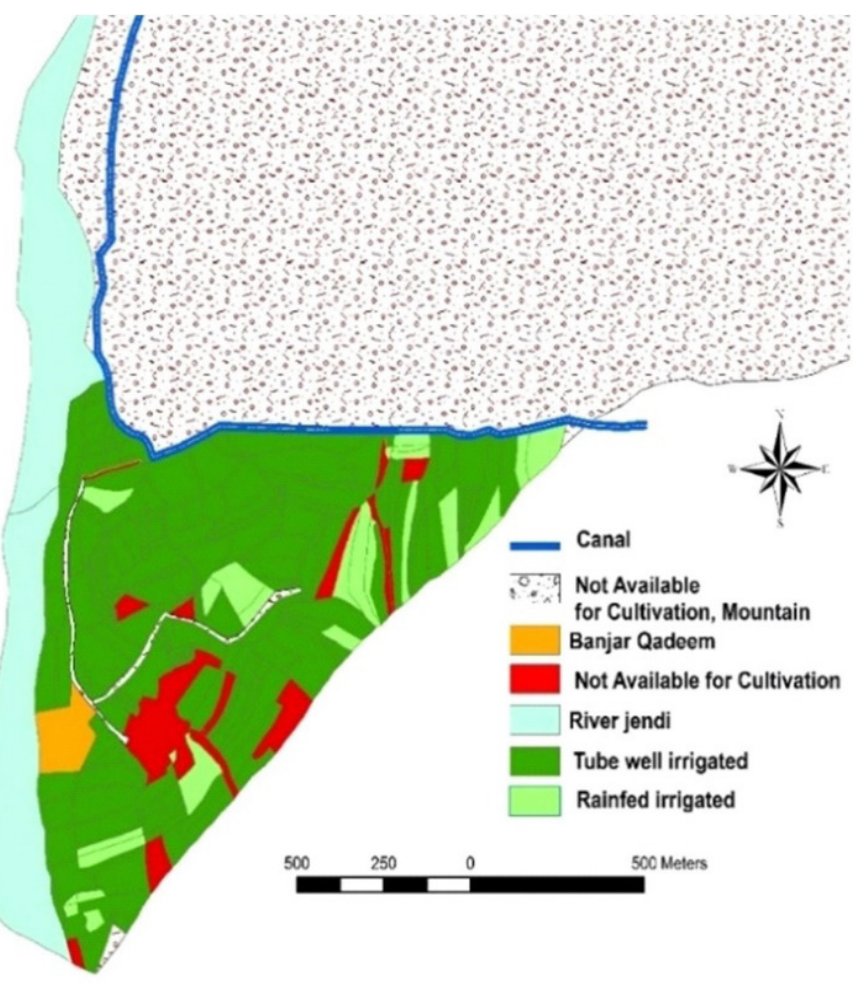

Figure 8: Source of irrigation, irrigation system of Mouza Qilla, 2008-09. Based on analysis of revenue record acquired from revenue office Tangi district Charsadda.

Rain-fed irrigation was dominant before dam construction, which is now being replaced by canal irrigation. According to a field survey, the water from the canal is highly variable which increases in summer and decreases in winter. This variable supply of water compelled the community to adopt an effective water distribution system. One such water distribution system is Warabandi. Warabandi is a rotational based irrigation system which is accomplished by assigning 
the entire flow of the watercourse to one farm for a specified period once every seven days (Qureshi and Hussain, 1994).

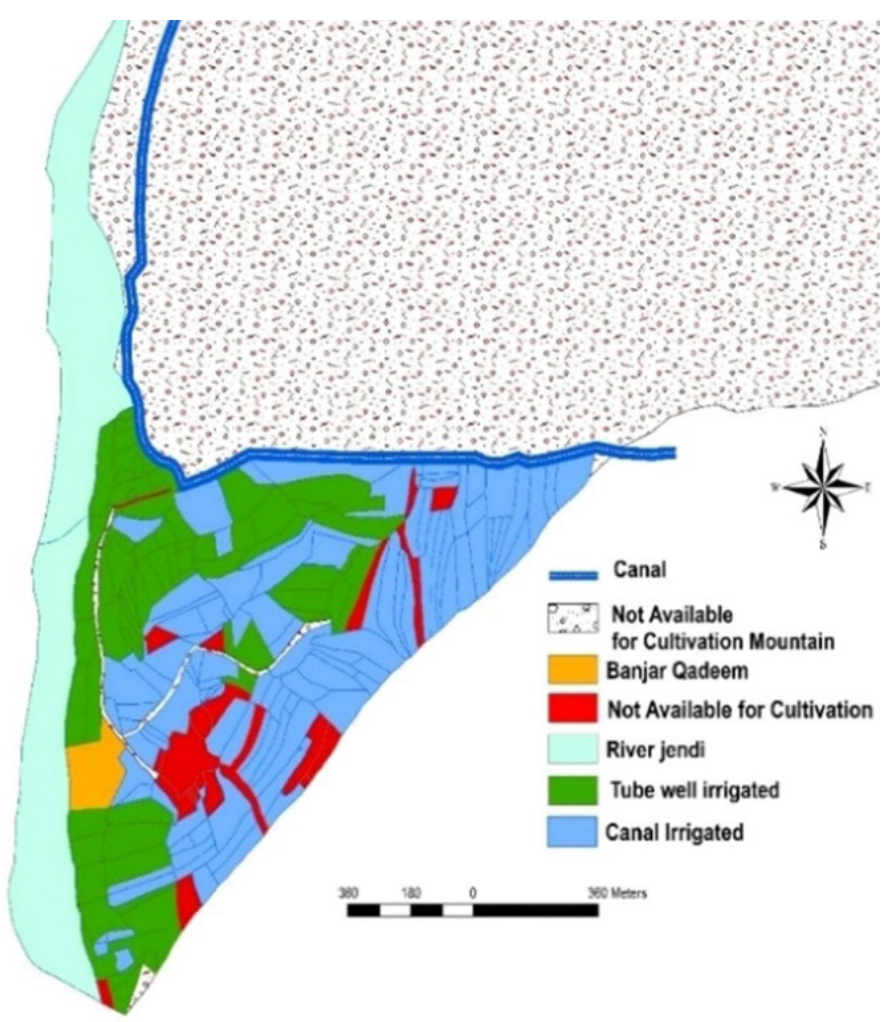

Figure 9: Source of irrigation, irrigation system of Mouza Qilla, 2016-17. Based on analysis of revenue record acquired from revenue office Tangi district Charsadda.

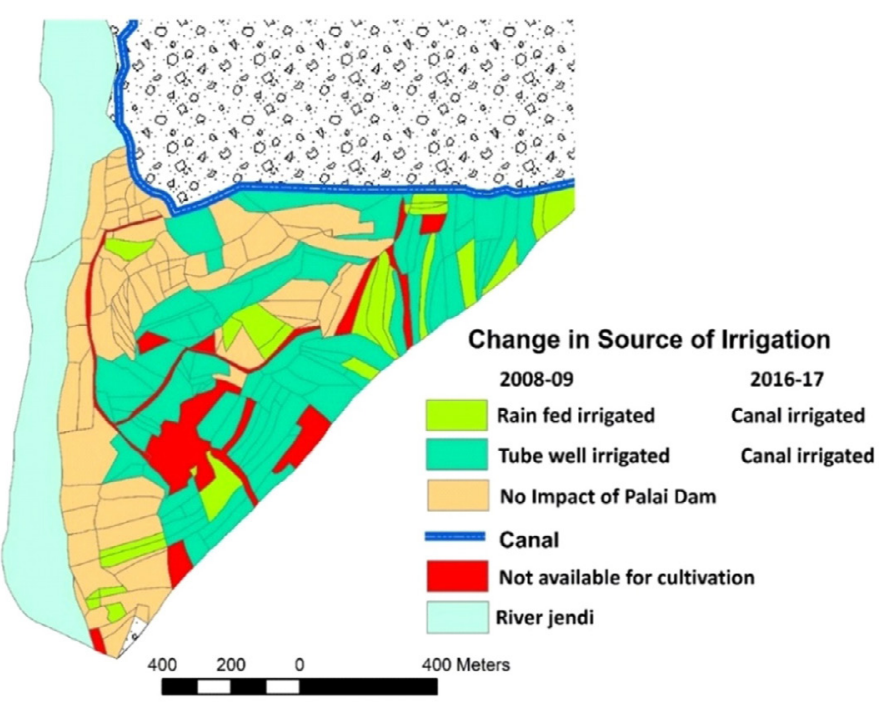

Figure 10: Change in the source of irrigation, irrigation system of Mouza Qilla, 2008-09 to 2016-17. Based on analysis of revenue record acquired from revenue office Tangi district Charsadda.

The term warabandi is consists of two words "wara" mean "turn" and "bandi" mean "fixed". In both the villages pacca warabandi is practiced. Pacca warabandi is officially recognized scheduled by the irrigation department in contrast to kaccha warabandi which is decided solely by farmers on their mutual agreement
(Qureshi and Hussain, 1994). Normally a farmer gets his turn in seven days or in some cases when the water is highly scarce the cycle became ten and a half days. However, there is some informal exchange of water turn among the farmers, usually within the farmers whose turn in warabandi falls within a short period. Some farmers reported selling water turns as well, which is a common practice in tubewell irrigation. In case of water disputes, which are not much common, the Divisional Officer call up a meeting of shareholders and fix up the duration and turns according to the location of landholding in the rotation register. In the Warabandi system generally, food crops are the top priority for irrigation followed by fodders.

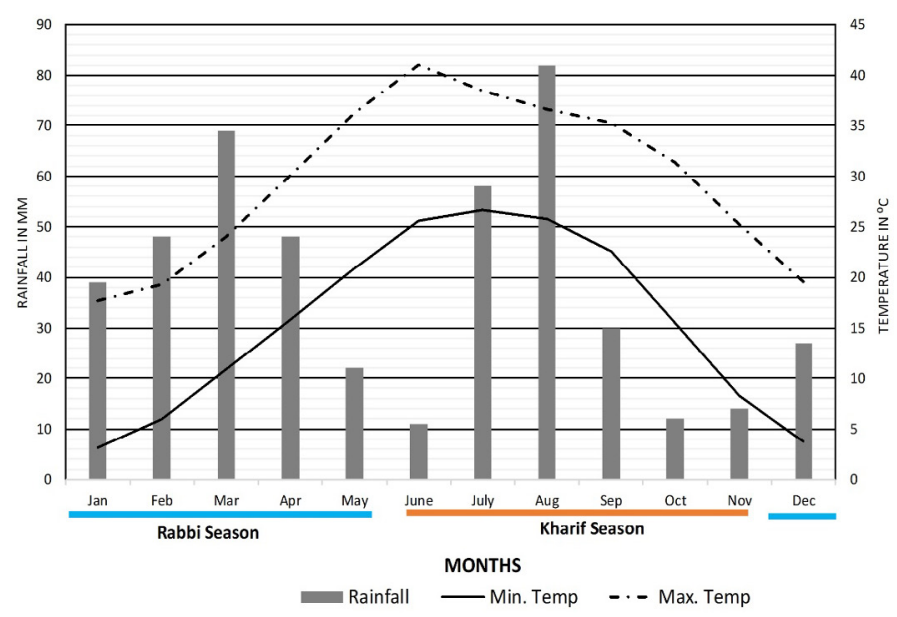

Figure 11: Climograph of District Charsadda.

\section{Conclusions and Recommendations}

The analysis of collected revenue records revealed a significant impact of the Palai dam on selected villages. Almost the same type of impact was recorded from both the villages; however, being one of the largest village Palai Nasratzai the impact is more prominent. In both the villages before the construction of the dam, the main source of irrigation was tubewells and rain-fed. But after the construction of the dam, canal irrigation accounted for over $50 \%$ of the irrigated area. This brought far-reaching changes in the cropping pattern of the selected villages. As a result of enough water availability, the traditional cropping pattern went under yielding changes. Farming is now being commercialized with the introduction of Sugarcane in Kharif and Onion in Rabi season (Muhammad et al., 2017). The study suggests that dams like the Palai dam are highly desirable and recommend the construction of more small dams in Khyber Pakhtunkhwa. Owing to the shortage of irrigation water, proper water management is essential for the development 
of agriculture. Therefore, proper management of irrigation water is highly recommended. The present study worked out that more water is available to the land located at the head of the canal than at the tail end. Both the village has the potential to increase the area under irrigation and in turn crop yield.

\section{Novelty Statement}

The research brings novelty by examining how the irrigation development bring far reaching changes in the cropping pattern of the Palai dam command area.

\section{Author's Contribution}

Muhammad Jamal Nasir: Conceived the concept and design database, handling, map making and wrote first draft.

Atiq Ur Rahman: Did field survey and collected secondary data from revenue office.

Anwar Saeed Khan: Reviewed the manuscript.

\section{Conflict of interest}

The authors have declared no conflict of interest.

\section{References}

Amede, T., 2015. Technical and institutional attributes constraining the performance of small-scale irrigation in Ethiopia. Water Res. Res. Dev., 6: 78-91. https://doi.org/10.1016/j. wrr.2014.10.005

Ashraf, M., M.A. Kahlown and A. Ashfaq. 2007. Impact of small dams on agriculture and groundwater development: A case study. Agric. Water Manage., 92: 90-98. https://doi. org/10.1016/j.agwat.2007.05.007

Ayala, G., M. Beyisa and G. Tadele. 2018. Assessment of status of irrigation practice and utilization in western Hararghe Zone, Oromia, Ethiopia. Civil Environ. Res., 10(5): 1-13.

Bacha, D., R. Namara, A. Bogale and A. Tesfaye. 2011. Impact of small-scale irrigation on household poverty: Empirical evidence from the Ambo District in Ethiopia. Irrig. Drain, 60: 1-10. https://doi.org/10.1002/ird.550

Burney,J.A., R.L. Naylor and L.S. Postel. 2013. The case for distributed irrigation as a development priority in sub-Saharan Africa. Proc. Natl.Acad. Sci. USA, 110(31): 12513-12517. https://doi. org/10.1073/pnas.1203597110

Fan, S., L. Zhang and X. Zhang. 2000. Growth and poverty in rural China: the role of public investment, research report No. 125. Int. Food Policy Res. Inst., Washington DC.

FAO, 1997. Irrigation Potential in Africa: A Basin Approach 4, FAO Land and Water Bulletin. Food and Agriculture Organization of the United Nations, Rome

FAO, 2015. FAO statistical pocketbook, world food and agriculture. Food and agriculture organization of the United Nations, Rome. Available at http://www.fao.org/3/a-i4691e.pdf

GoKP, 1994. Palai Dam project, feasibility report. Irrigation department, small Dams directorate, Peshawar.

GoKP, 2016. Development statistics of Khyber Pakhtunkhwa. Bureau of Statistics, Planning and Development.

Hagos, F., G. Jayasinghe, S.B. Awulachew, M. Loulseged and A.D. Yilma. 2012. Agric. Water Manage. Poverty Ethiopia. Agric. Econ., 43: 99-111. https://doi.org/10.1111/j.15740862.2012.00623.x

Hazell, P.B.R., 2009. The Asian green revolution. International food policy research institute (IFPRI) Discussion Paper 00911. https:// core.ac.uk/download/files/153/6257689.pdf (Accessed September 28, 2018). https://doi. org/10.1029/2008GB003435

Jin, S., J. Huang, R. Hu and S. Rozelle. 2002. The creation and spread of technology and total factor productivity in China's agriculture. Am. J. Agric. Eco., 84: 916-930. https://doi. org/10.1111/1467-8276.00043

Lata, S., 2019. Impact of irrigation on agricultural development: A correlative analysis. Irrig. Water Manage. Agric. Dev. Uttar Pradesh, India. Springer, Cham. pp. 315-347. https://doi. org/10.1007/978-3-030-00952-6_7

Mati, B.M., 2008. Capacity development for smallholder irrigation in Kenya. Irrig. Drain, 57: 332-340. https://doi.org/10.1002/ird.437

Muhammad, J.N., A.S. Khan, S. Alam and S. Akhtar. 2017. Impacts of Palai dam on land use and cropping pattern of Mouza Qilla, District Charsadda, Khyber Pakhtunkhwa, Pakistan. Sarhad J. Agric., 33(1): 80-89. https://doi. org/10.17582/journal.sja/2017.33.1.80.89

Namara, R.E., G. Gebregziabher, M. Giordano and C. De Fraiture. 2013. Small pumps and poor 
farmers in Sub-Saharan Africa: An assessment of current extent of use and poverty outreach. Water Int., 38(6): 827-839. https://doi.org/10 $.1080 / 02508060.2014 .847777$

Portmann, F.T., S. Siebert and P. Doll. 2010. MIRCA2000 Global monthly irrigated and rain-fed crop areas around the year 2000: A new high-resolution data set for agricultural and hydrological modeling. Glob. Biogeoch. Cycles, 24(1): 1-24. https://doi. org/10.1029/2008GB003435

Qureshi, S.K. and Z. Hussain. 1994. An assessment of warabandi (irrigation rotation) in Pakistan: A preliminary analysis. Pak. Dev. Rev., 33(4): 845-855. https://doi.org/10.30541/ v33i4IIpp. $845-855$

Schultz, B., C.D. Thatte and V.K. Labhsetwar. 2005. Irrigation and drainage main contributors to global food production. Irrig. Drain., 54: 263278. https://doi.org/10.1002/ird.170

Shah, T., S. Verma and P. Pavelic. 2013. Understanding smallholder irrigation in SubSaharan Africa: Results of sample survey from nine countries. Water Int., 38(6): 809-826. https://doi.org/10.1080/02508060.2013.8438 43

Tolera, T., 2017. The Problems, Opportunities and Implications of Small Scale Irrigation for Livelihood Improvement in Ethiopia-A Review. Civil Environ. Res., 9(12): 27-34.

Tolera,T., B. Legesse,M.Aman and T. Etensa.2017. Economic valuation of improved irrigation water use: The case of Woliso District, South West Shoa Zone, Oromia National Regional State, Ethiopia. J. Eco. Sust. Dev., 8(13): 58-63. 